\title{
A Power Monitoring System of Machine Tool
}

Ma Qinyi, Lu Mingyue, Shi Junli, Jin Haihua, Wang Yajun, Zhou Maojun

School of Mechanical Engineering and Automation, Dalian Polytechnic University, Dalian Liaoning 116034, China. Email:18003614051@163.com, maqy@dlpu.edu.cn, shij1@dlpu.edu.cn, jinhh@dlpu.edu.cn, wangyajun2004@hotmail.com,zhoumj@dlpu.edu.cn

This paper completes a design of power monitoring system of machine tool based on MSP430F149 microcontroller. This system is mainly divided into four modules: the electric energy information input and processing module, electric energy metering operation processing module, Single-Chip Microcomputer system internal data processing module, and PC memory module, respectively. The voltage transformer and current transformer collect voltage signal and current signal respectively, which were inputted deferentially to the ATT7022A voltage channel and current channel, to achieve electric energy information input and processing. The special measure chip ATT7022A measures the three-phase active power, reactive power, apparent power, active energy and reactive energy to meter and operate electric energy. MCU system processing module communicates with ATT7022A chip via the SPI bus interface by using the 16 bit MSP430F149 microcontroller. The establishment of database model and database table using the relatively practical method of entity-relationship achieves PC internal data memory module. In addition, the fabrication of PCB circuit board and software writing are also introduced in detail in this paper.

Keywords: machine tool, power monitoring system, MSP430F149

\section{Acknowledgments}

This project is supported by National Natural Science Foundation of China (Grant No. 51305051), the Liaoning Province Natural Science Foundation (Grant No. 2014026006), and Dalian Polytechnic University Training Programs of Innovation and Entrepreneurship for Undergraduates (Grant No. 201410152141).

\section{References}

[1] VERSEN, M., KIPFELSBERGER, S. (2014). Introduction to microcomputer technology with the MSP430 Launch Pad in remote labs. In: Proceedings of Global Engineering Education Conference (EDUCON) (Aprial), pp. 202-205.

[2] GASPAR, P.D., SANTO, A.E., RIBEIRO, B. (2010). MSP430 microcontrollers essentials - A new approach for the embedded systems courses: Part 3 - Data acquisition and communications. In: Proceedings of Education and Research Conference (EDERC) (Dec), pp. 205-209.

[3] XING, Y.H., WANG, R. (2010). Remote CO Measurement Based on MSP430 Processor Used with GSM module. In: Proceedings of 2010 International Conference on Electrical and Control Engineering (ICECE) (June), pp. 5439-5442.

[4] GENG, L.W. (2010). Current Measurement Device Design Based on MSP430 Single-Chip Microcontroller. In: Proceedings of 2010 International Conference on E-Product E-Service and E-Entertainment (ICEEE) (Nov), pp. 1-9.

[5] HANG, J.W., ZHANG, Y.Q. (2013). Monitoring System of Machine Tools Based On the InTouch. In: Proceedings of 2013 International Conference on Mechanical and Automation Engineering (Nov), pp. 70-72.

[6] ZHANG, Z.J. (2010). Based on Industrial Ethernet Networking of CNC Machine Tool Monitoring System Design. In: Proceedings of 2010 International Conference on Internet Technology and Applications (Aug), pp. 20-22.

[7] DANIEL, A., SOLON, D.C., ABD-EL-KADER, S. etc. (1990). A monitoring system for NC machine tool. In: Proceedings of 16th Annual Conference of Industrial Electronics Society (Dec), pp. 622-626.

[8] CLAUDIA, G.M., GILBERTO, H.R., GEZA, H. etc. (1992). Multiprocessor based machine tool monitoring systém. In: Proceedings of Third International Conference on Competitive Performance Through Advanced Techno$\log y(\mathrm{Dec}), \mathrm{pp} .208-211$.

[9] U-IL JANG, MIN-SEOK NOH, KOOK-JIN CHOI etc. (2008). Development of a Web-Based Remote Monitoring System for Evaluating Degradation of Machine Tools Using ART2. In: Proceedings of IEEE/ASME International Conference on Mechtronic and Embedded Systems and Applications (June), pp. 315-320. 
[10] LOU, K.N., LEE, C.T. (1995). An intelligent on-line tool monitoring system in milling processe. In: Proceedings of IEEE International Conference on Systems, Man and Cybernetics, Intelligent Systems for the 21st Century (June), pp. 2651-2656.

[11] NOVAK, M., DOLEZAL, R. (2012). G-Ratio in hardened steel grinding with different coolant. In Manufacturing Technology, vo. 12, No. 13, pp. 192-197.

[12] RAD, J.S., ZHANG Y.M., CHEN, Z.C. (2014). A study on tool wear monitoring using time-frequency transformation techniques. In: Proceedings of 2014 International Conference on Innovative Design and Manufacturing (ICIDM) (Aug), pp. 342-347.

[13] LI, P.Y., LI, Y., YANG, M.S. (2008). Monitoring Technology Research of Tool Wear Condition Based on Machine Vision. In: Proceedings of the 7th World Congress on Intelligent Control and Automation (June), pp. 27832787.

[14] WEN, X.L., LIU, Z.Y. (2008). Design of Inspecting System Based on MSP430F149 SCM and Wireless Communication Technology. In: Proceedings of 2008 International Seminar on Future BioMedical Information Engineering (Dec), pp. 231-234.

[15] WEI, J., XIE, P., FENG, G.Q. (2010). Wireless Temperature Measurement and Control System Based on MSP430F149. In: Proceedings of 2010 Fourth International Conference on Genetic and Evolutionary Computing (ICGEC) (Dec), pp. 822-825.

[16] UTTARKAR, N.K., KANCHI, R.R. (2013). Design and development of a low-cost embedded system laboratory using TI MSP430F149. In: Proceedings of 2013 International Conference on Communications and Signal Processing (ICCSP) (April), pp. 165-175.

[17] TAO, W.Q., ZHANG, Q., CUI, B.J. (2008). The design of Energy Management Terminal Unit based on double MSP430 MCU. In: Proceedings of China International Conference on Electricity Distribution (Dec), pp. 10 - 13.

[18] ZHANG, X., FU, Y.X., WANG, Y.G. (2012). Design and implementation of smart home monitoring system based on MSP430. In: Proceedings of 2012 IEEE Symposium on Electrical \& Electronics Engineering (EEESYM) (June), pp. 102-105. 